\title{
Therapeutic efficacy of combined blockade of CTLA-4 +/- PD-L1 +/- IDO is associated with re-activation of $T$ cells directly within the tumor microenvironment
}

\author{
Stefani Spranger ${ }^{*}$, Thomas Gajewski \\ From Society for Immunotherapy of Cancer 28th Annual Meeting \\ National Harbor, MD, USA. 8-10 November 2013
}

A major subset of human cancers is associated with $\mathrm{CD} 8+\mathrm{T}$ cell infiltration yet tumor rejection fails due to the dominant effects of multiple immune inhibitory mechanisms. These include expression of the inhibitory receptors CTLA- 4 and PD- 1 by $\mathrm{T}$ cells and expression of the tryptophan-catabolizing enzyme indoleamine-2,3dioxygenase (IDO) within the tumor microenvironment. It has been anticipated, therefore, that combined blockade of two or more inhibitory pathways may be necessary for maximal therapeutic benefit. Using the B16.SIY transplantable tumor model, we found that administration of doublets of $\alpha$ CTLA-4, $\alpha$ PD-L1 or an IDOi led to strikingly effective immune-mediated tumor control in vivo. We examined whether the potent therapeutic effect of these combinations might be attributed to increased priming versus restored function of $\mathrm{T}$ cells within the tumor microenvironment. Analysis of SIY-specific T cell responses in the tumor-draining lymph node or spleen early following therapy revealed only a minimal elevation with the doublets. However, within the tumor-microenvironment, each of the effective combinations was associated with markedly augmented proliferation and IL-2 production by tumor-infiltrating CD8+ T cells. No major depletion of Tregs was detected in the tumor site. In order to assess whether this increased function of tumorinfiltrating lymphocytes (TILs) was intrinsic to those cells or required new T cell entry, the S1P inhibitor FTY720 was utilized. Administration of FTY720 resulted in near total loss of circulating $\mathrm{T}$ cells. However, the restoration of IL-2 production and proliferation of CD8+ TILs was still observed. At later times points, after tumor rejection

Pathology, University of Chicago, Chicago, IL, USA was proceeding, increased frequencies of SIY-specific $T$ cells were observed in the circulation. $\alpha$ CTLA-4 plus $\alpha \mathrm{PD}-\mathrm{L} 1$ treatment also resulted in significant tumor control in the BrafV600E/PTEN-/- genetic tumor model. Our results suggest that combinatorial immunotherapies with potent synergy share the property of augmenting IL2 production and proliferation by TILs directly within the tumor. These are attractive combination therapies for clinical translation, and examination of TIL proliferation should be pursued as a pharmacodynamic biomarker in the clinic.

Published: 7 November 2013

doi:10.1186/2051-1426-1-S1-08

Cite this article as: Spranger and Gajewski: Therapeutic efficacy of combined blockade of CTLA-4 +/- PD-L1 +/- IDO is associated with re-activation of $\mathrm{T}$ cells directly within the tumor microenvironment. Journal for ImmunoTherapy of Cancer 2013 1(Suppl 1):O8.

Submit your next manuscript to BioMed Central and take full advantage of:

- Convenient online submission

- Thorough peer review

- No space constraints or color figure charges

- Immediate publication on acceptance

- Inclusion in PubMed, CAS, Scopus and Google Scholar

- Research which is freely available for redistribution
@ 2013 Spranger and Gajewski; licensee BioMed Central Ltd. This is an Open Access article distributed under the terms of the Creative Commons Attribution License (http://creativecommons.org/licenses/by/2.0), which permits unrestricted use, distribution, and reproduction in any medium, provided the original work is properly cited. 